\title{
SPATIAL VARIABILITY AND VITALITY OF EPIGEOUS TERMITE MOUNDS IN PASTURES OF MATO GROSSO DO SUL, BRAZIL
}

\author{
Sandra Santana Lima(1), Marcos Bacis Ceddia(1), Fernando Zuchello(1), Adriana Maria de \\ Aquino(2), Fábio Martins Mercante(3), Bruno José Rodrigues Alves(2), Segundo Urquiaga(2), \\ Christopher Martius(4) and Robert Michael Boddey(2)*
}

\footnotetext{
(1) Universidade Federal Rural do Rio de Janeiro, Instituto de Agronomia, Departamento de Solos, Seropédica, Rio de Janeiro, Brasil.

(2) Empresa Brasileira de Pesquisa Agropecuária, Seropédica, Rio de Janeiro, Brasil.

(3) Empresa Brasileira de Pesquisa Agropecuária, Dourados, Mato Grosso do Sul, Brasil.

(4) Center for Development Research (ZEF), University of Bonn, Bonn, Germany.

* Corresponding author.

E-mail: robert.boddey@embrapa.br
}

\begin{abstract}
Epigeous termite mounds are frequently observed in pasture areas, but the processes regulating their population dynamics are poorly known. This study evaluated epigeous termite mounds in cultivated grasslands used as pastures, assessing their spatial distribution by means of geostatistics and evaluating their vitality. The study was conducted in the Cerrado biome in the municipality of Rio Brilhante, Mato Grosso do Sul, Brazil. In two pasture areas (Pasture 1 and Pasture 2), epigeous mounds (nests) were georeferenced and analyzed for height, circumference and vitality (inhabited or not). The area occupied by the mounds was calculated and termite specimens were collected for taxonomic identification. The spatial distribution pattern of the mounds was analyzed with geostatistical procedures. In both pasture areas, all epigeous mounds were built by the same species, Cornitermes cumulans. The mean number of mounds per hectare was 68 in Pasture 1 and 127 in Pasture 2, representing 0.4 and $1 \%$ of the entire area, respectively. A large majority of the mounds were active (vitality), $91 \%$ in Pasture 1 and $84 \%$ in Pasture 2. A "pure nugget effect" was observed in the semivariograms of height and nest circumference in both pastures reflecting randomized spatial distribution and confirming that the distribution of termite mounds in pastures had a non-standard distribution.
\end{abstract}

Keywords: termites, Isoptera, geostatistics, spatial distribution. 


\title{
RESUMO: VARIABILIDADE ESPACIAL E VITALIDADE DE NINHOS EPÍGEOS DE TÉRMITAS EM PASTAGENS DE MATO GROSSO DO SUL, BRASIL
}

\begin{abstract}
Ninhos epígeos são frequentemente observados em áreas de pastagem; no entanto, os processos que regulam as suas dinâmicas populacionais são pouco conhecidos. Este estudo avaliou a distribuição espacial por meio da geoestatística e a vitalidade dos ninhos epígeos de térmitas em áreas de pastagens introduzidas. Esta pesquisa foi conduzida no bioma Cerrado no município de Rio Brilhante, no Estado do Mato Grosso do Sul, Brasil. Em duas áreas de pastagem (Pasto 1 e Pastagem 2), ninhos epígeos foram georreferenciados; analisaram-se altura, circunferência e vitalidade (habitado ou não). A área ocupada pelos ninhos foi calculada, e as amostras de térmitas foram coletadas para identificação taxonômica. $O$ padrão de distribuição espacial dos ninhos foi analisado com procedimentos geoestatisticos. Em ambas as áreas de pastagem, todos os ninhos epígeos foram construídos por uma mesma espécie, Cornitermes cumulans. O número médio de ninhos ha-1 foi de 68 no pasto 1 e 127 no pasto 2 , o que representa 0,4 e $1 \%$ de toda a área, respectivamente. A grande maioria dos ninhos estava ativa, $91 \%$ no pasto 1 e $84 \%$ no pasto 2. Os semivariogramas de altura e circunferência dos ninhos em ambas as pastagens apresentou um "efeito pepita puro", refletindo distribuição espacial aleatória e confirmando que a distribuição dos ninhos epígeos de térmitas em pastagens não segue uma distribuição-padrão.
\end{abstract}

Palavras-chave: cupins, Isoptera, geoestatística, distribuição espacial.

\section{INTRODUCTION}

In tropical ecosystems, termites are among the most important soil invertebrate groups for playing an essential role in decomposing processes, nutrient cycling and changes in soil properties (Lee and Wood, 1971; Holt and Lepage, 2000; Korb and Linsenmair, 2001). Many other organisms depend on termites as a source of food and organic matter, or use their mounds for shelter (Constantino and Schlemmermeyer, 2000). In the Brazilian Cerrado, termite mounds are abundant, and some types have a high population density (Lima-Ribeiro et al., 2006). In cultivated pastures of this region, termite populations can be very high as indicated by large densities of mounds, but the diversity of species is greatly reduced.

Species that feed on soil can either build their mounds on the surface or underground (Oliveira et al., 2011). These mounds have different shapes and characteristics, depending on the termite species. Constantino (2005) classified these mounds as epigeous, subterranean, arboreal and within a single piece of wood. According to Bandeira and Martius (2009), one mound usually represents one colony. There are, however, species whose colonies may have two or more sub-mounds spread over large areas, that is, polycalic or compound mounds (Martius, 2001).

Termite colonies can contain thousands and even millions of individuals (Bandeira and Vasconcellos, 2004). A mature colony produces winged termites that can establish new colonies. Termite flights usually occur once a year, when mature nymphs develop wings and transform themselves into adult imagoes or 'alates' (Bandeira and Martius, 2009). This phenomenon is primarily seasonal and associated with climatic variations, especially heat and relative humidity (Rebello and Martius 1994; Medeiros et al., 1999; Martius, 2003). Flights of the same species in the same area are synchronized (Cancello and Schlemmermeyer, 1999).

The spatial distribution of termites mounds is related to environmental characteristics such as altitude, temperature, rainfall, local availability of food resources and nesting; as well as intraand inter-specific relationships and degree of environmental disturbance (Eggleton et al., 2002; Florencio and Diehl, 2006). Species that build epigeous mounds, such as Cornitermes cumulans, can reach high population densities, especially in open environments (Constantino, 2005), such as pastures.

According to Cunha and Morais (2010), the implantation of pastures often increases mound density because of the environmental homogeneity and absence of competitors. Despite the beneficial importance of termites to soil processes the useful pasture area can be reduced by very dense populations of epigeous mounds (Valério, 1995), which has led cattle farmers to find ways to destroy the mounds (Ávila and Goulart, 1995). Termite mounds have been commonly associated with pasture degradation, but this hypothesis has been recently refuted by Lima et al. (2011) in an evaluation of soil and plant parameters in Cerrado areas.

The spatial distribution of mounds may be an indicator of underlying mechanisms regulating population dynamics (Korb and Linsenmair, 2001), For instance, regular spacing may indicate intra-specific competition or density-dependent predation. Clumped distribution patterns may be the product of incomplete dispersion (i.e. when 
new termite colonies are founded by alates whose 'nuptial flights' end not very far from the mother colony). The spatial distribution of termites has been studied using various methods. Clark and Evans (1954) and later, Korb and Linsenmair (2001), evaluated spatial variability by a distance index using the nearest-neighbor technique. Geostatistical techniques were applied by Crist (1998) to assess the spatial distribution of subterranean termites, and more recently, Grohmann et al. (2010) analyzed mound distribution using Ripley's K function, pair correlation function and similar techniques, to analyze mound distribution patterns of a fungusgrowing termite species.

In Brazil, studies on the spatial distribution of termites were conducted by Bruschini (2006), who applied the Clark and Evans (1954) distance index, and by Cunha (2011), who analyzed the spatial distribution of mounds by dispersion and clustering. Martius (2003) mapped termite distribution in a varzea floodplain forest and associated it to environmental parameters such as flooding. Understanding the processes that regulate the population dynamics of termites is particularly important since the distribution is regulated at two stages in the lifetime of a termite colony, with different factors affecting the founding alates than the established colony. Mounds can be prominent landscape features even after the colony that built them died. Therefore, counting mounds without assessing their vitality can lead to an overestimation of the termite population. Only assessing the vitality allows a true diagnosis of termite occupation; this information has been ignored in many surveys conducted in Brazilian pastures with epigeous mounds.

The semivariogram analysis can show whether the spatial distribution of vitality, height and circumference of termite mounds is random or spatially dependent. We hypothesized that if the spatial distribution is not random, some (biotic and/or abiotic) factors are controlling the dynamics of termite mounds. Therefore, the purpose of this study was to apply geostatistical methods to assess the spatial distribution of epigeous termite mounds in pasture areas and to evaluate their vitality.

\section{MATERIAL AND METHODS}

The study was carried out in a pasture area of the Fazenda Campana in Rio Brilhante, Mato Grosso do Sul $\left(22^{\circ} 16^{\prime} 29^{\prime \prime} \mathrm{S}\right.$; $54^{\circ} 48^{\prime} 57^{\prime \prime} \mathrm{W}$ and altitude of $353 \mathrm{~m}$ asl). This area, covered with Cerradão vegetation, characterized by a continuous vegetation canopy and tree cover that can range from 50 to $90 \%$, is part of the Cerrado biome, where the climate is tropical with a dry season
(Köppen-Geiger classification Aw). The mean annual temperature is $20^{\circ} \mathrm{C}$, ranging from 18 to $22^{\circ} \mathrm{C}$, and annual rainfall between 1,500 and $1,750 \mathrm{~mm}$. The predominant soil type in the region is Latossolo Vermelho (Oxisol) (Embrapa, 2006).

Two cultivated pastures with Brachiaria brizantha (cv. Marundu) consisting of two paddocks with a total area of nearly 60 ha were selected for their management history, proximity, topographic similarity, age and a contrast, first assessed visually only, in terms of termite mound density. In each area, cattle grazed in a rotational system, moving from one paddock to another every 7 to 8 days. After pasture establishment 1992, the areas had been maintained without fertilizer. One area had more epigeous mounds and a lower number of trees and shrubs (Pasture 1); the other area (Pasture 2) had lower nest density and a higher number of trees and shrubs.

In each pasture, four continuous 1-ha paddocks were demarcated. A large paddock area was used to enhance the accuracy of mound distribution assessment and because it was suitable for geostatistical methods, which require sampling point insertion into a grid. The mean number of mounds ha-1 was calculated based on the nests counted per plot.

Mound evaluation and termite collection were performed in May 2010 (Pasture 1) and May 2011 (Pasture 2). One 1.0-ha plot per pasture was randomly selected to study spatial variability. Plot 1 was chosen in Pasture 1 and plot 3 in Pasture 2 (highlighted plots in figure 1). The epigeous mounds in each plot were georeferenced using a GPS (Trimble Pathfinder - ProXT) with horizontal precision of $\pm 0.8 \mathrm{~m}$ and vertical precision of $\pm 1.3 \mathrm{~m}$. Next, the height, circumference and vitality (termite presence) of each mound were evaluated. Mound vitality was assessed in the early morning and late afternoon, by observations of the external aspect of the mound, and detection of termite presence or absence when perforating the mounds with an iron shovel. In some cases, the mounds were destroyed to certify that they had been completely abandoned.

The area occupied by the mounds in pastures 1 and 2 was calculated from the relationship between the sum of areas occupied by the mounds in the chosen plots and the total area of the plots (1 ha), as shown in equation 1 :

$$
\mathrm{A}_{\mathrm{tn}}(\%)=\left(\frac{\sum_{i=1}^{n}\left(\pi \times r^{2}\right)}{10,000}\right) \times 100
$$

where: $A_{\text {tn }}(\%)$ is the area (\%) occupied by epigeous mounds in a chosen plot; and $r$ the radius of each epigeous mound. 
The radius of each mound was determined from its circumference, according to equation 2 :

$$
\mathrm{r}=\left[\frac{c}{2 \pi}\right]
$$

where: $c$ is the circumference at the base of the mound, measured in the field.

For species identification, $10 \%$ of the mounds were separated into their epigeous and underground portions to sample all castes of the colony. Samples were stored in flasks with $80 \%$ alcohol for further taxonomic identification. Identification of the species and morphospecies level was performed according to Cancello (1989) and Constantino (1999), at the Zoology Museum of the University of São Paulo (MZUSP). After identification, part of the material was added to the MZUSP collection.

Descriptive analysis and geostatistics were performed using GEOESTAT software, according to Vieira et al. (1983). Descriptive analysis was performed using the STAT.EXE module of the software to check for normal distribution of the dataset and detect outliers. The AVARIO.EXE module was then used to analyze the spatial dependence of termite mounds based on mound height and circumference. The AVARIO.EXE module calculates the semivariance of "mound height" and "circumference", by the following equation:

$$
\gamma(h)=\frac{1}{2 N(h)} \sum_{i=1}^{N(h)}\left[Z\left(\chi_{i}\right)-Z\left(\chi_{i}+h\right)\right]^{2}
$$

where $\gamma(\mathrm{h})$ : semivariance estimated at distance $\mathrm{h}$; $\mathrm{N}(\mathrm{h})$ : number of pairs of values [Z(x i), $\mathrm{Z}(\mathrm{x} \mathrm{i}+\mathrm{h})]$ separated by the $h$ vector; $x_{i}$ spatial position of the $\mathrm{Z}$ variable; and $\mathrm{Z}$ : values of the variables (mound height and circumference).

Semivariance graphs (semivariograms) were constructed and adjusted to numerical models using Microsoft Excel. Maps of the spatial variability of termite mound properties were produced using Surfer 7.02 software (Golden Software, 2000).

\section{RESULTS AND DISCUSSION}

All mounds in both pastures had been constructed by a single termite species (Cornitermes cumulans). In Pasture 1, the mean number of mounds ha-1 was 68 , and 71 were selected in a plot for spatial analysis. Pasture 2 contained 127 mounds, with 115 in the selected plot (Table 1). The selected mounds occupied 0.4 and $1 \%$ of the total area of Pastures 1 and 2 , respectively.

Altitude, mound heights and circumferences were similar in both areas (Table 2). The coefficients of variation (CV) for altitude were consistently low
Table 1. Number of termite mounds in the plots and mean number of mounds per pasture on the Fazenda Campana, Rio Brilhante, MS

\begin{tabular}{lcccccc}
\hline & Plot 1 & Plot 2 & Plot 3 & Plot 4 & Mean & $\mathbf{A}_{\mathbf{t n}}{ }^{(1)}$ \\
\hline & & & & & & $\%$ \\
Pasture 1 & 71 & 62 & 77 & 63 & 68.3 & 0.4 \\
Pasture 2 & 90 & 195 & 115 & 108 & 127.0 & 1.0 \\
\hline
\end{tabular}

(1) $\% A_{t n}$ : percent of the area occupied by epigeous mounds in the plot selected.

due to the flat topography in both areas. For mound circumference and height, CVs were high. The distribution of data frequency was asymmetric and in general close to zero, particularly in Pasture 1. The highest asymmetry value was found for altitude data in Pasture 2. However, data distribution can be assumed to be close to normal. The average mound height observed in the two areas was 65 and $59 \mathrm{~cm}$ in Pasture 1 and 2, respectively, and the maximum height was $130 \mathrm{~cm}$. The basal circumference of the mounds ranged from 0.1 to $3.9 \mathrm{~m}$ in Pasture 1 and from 0.6 to $3.4 \mathrm{~m}$ in Pasture 2, with means of 2.58 and $2.26 \mathrm{~m}$, respectively.

The correlation coefficients between the circumference and height of epigeous mounds were high and significant $(\mathrm{p}<0.05$; Table 3$)$, but these variables were not associated to altitude, as expected, given the low altitude variation. Mound circumference was highly correlated to height, as the highest mounds tended to have a higher base circumference.

Table 2. Descriptive statistical analysis of data of epigeous termite mounds

\begin{tabular}{lccc}
\hline Parameter & Altitude & Circumference & Height \\
\hline & m asl & $\mathrm{m}$ & $\mathrm{cm}$ \\
& Pasture 1 & & \\
Minimum value & 330.6 & 1.00 & 20.0 \\
Maximum value & 334.6 & 3.90 & 130.0 \\
Mean & 332.7 & 2.58 & 65.7 \\
Asymmetry & -0.001 & -0.51 & 0.19 \\
Kurtosis & -1.210 & -0.75 & -0.88 \\
CV (\%) & 0.330 & 28.82 & 42.60 \\
Standard deviation & 1.11 & 0.74 & 27.96 \\
& Pasture 2 & & \\
Minimum value & 323.2 & 0.60 & 10.0 \\
Maximum value & 329.7 & 3.44 & 128.0 \\
Mean & 325.6 & 2.26 & 59.5 \\
Asymmetry & 0.70 & -0.38 & 0.21 \\
Kurtosis & -0.77 & -1.03 & -0.72 \\
CV (\%) & 0.54 & 31.62 & 46.40 \\
Standard deviation & 1.76 & 0.71 & 27.58 \\
\hline
\end{tabular}


Table 3. Matrix of correlation between sizes of epigeous termite mounds

\begin{tabular}{lccr}
\hline & Altitude & Circumference & Height \\
\hline Altitude & \multicolumn{3}{c}{ Pasture 1 } \\
Circumference & 0.2963 & 1.000 & \\
Height & 0.2863 & 0.803 & 1.000 \\
& & Pasture 2 & \\
Altitude & 1.0000 & & \\
Height & 0.0659 & 1.0000 & 1.000 \\
Circumference & 0.0849 & 0.8163 & \\
\hline
\end{tabular}

In both pasture areas, data were recorded in Plot 1.Values without bold indicate no statistical significance (Pearson's correlation, $\mathrm{p}<0.05$ ).

The semivariograms of mound measurements in Pasture 1 (Figures 1 and 2), show a "pure nugget effect" for height and circumference. According to Vieira (2000), an experimental semivariogram with a pure nugget effect for a property means that its spatial distribution is random. This pattern can be visualized using experimental semivariance values $\left(\gamma_{(\mathrm{h})}\right)$ at short distances (5 to $\left.15 \mathrm{~m}\right)$. In Pasture 1, height and circumference measures of the closest mounds (approximately $15 \mathrm{~m}$ ) were more divergent than those of mounds separated by larger distances. In Pasture $2, \gamma_{(\mathrm{h})}$ values were practically the same at any distance, confirming the random distribution pattern.

In Plot 1 of Pasture 1, $91 \%$ of the mounds were active, and $84 \%$ were active in Plot 3 of Pasture 2. Spatial variability maps show vitality distribution (Figure $3 \mathrm{a}, \mathrm{c}$ ) and its relationship to mound size (Figure 3b,d). Vitality distribution was particularly associated with mound height, indicating that the largest mounds were usually active, mainly in Pasture 2, where most abandoned mounds were found.

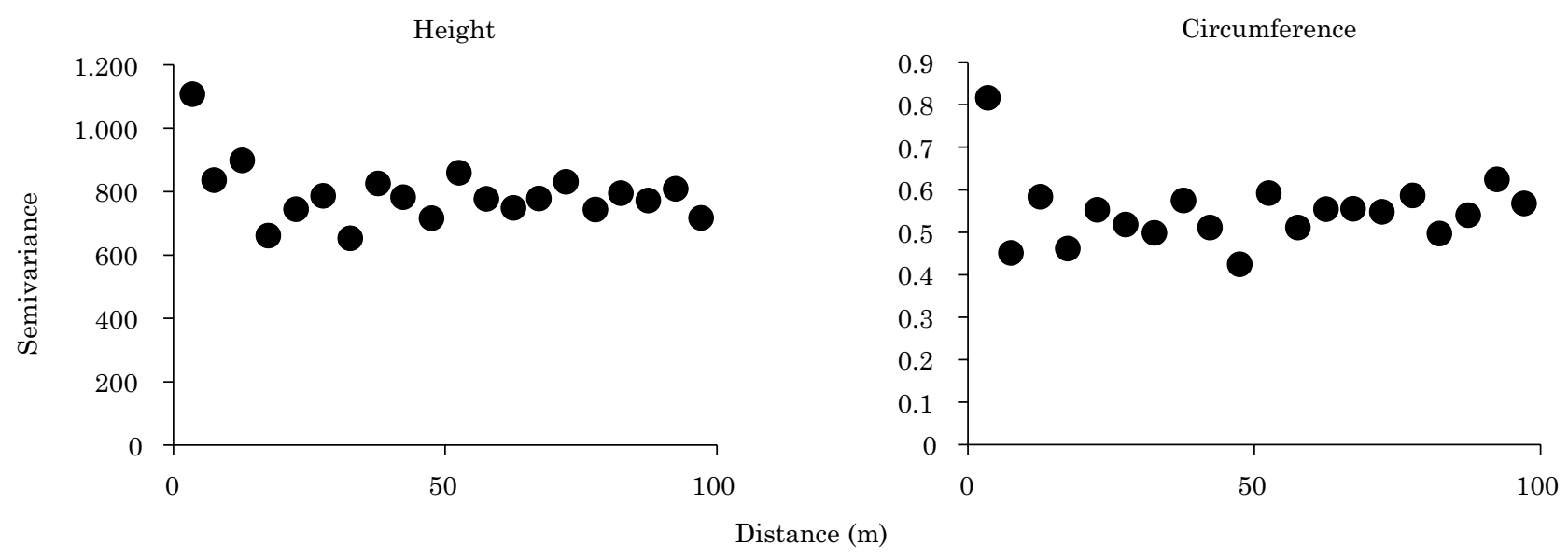

Figure 1. Semivariogram of termite nest circumference and height evaluated in Plot 1 from Pasture 1 , on the Fazenda Campana, Rio Brilhante, MS.

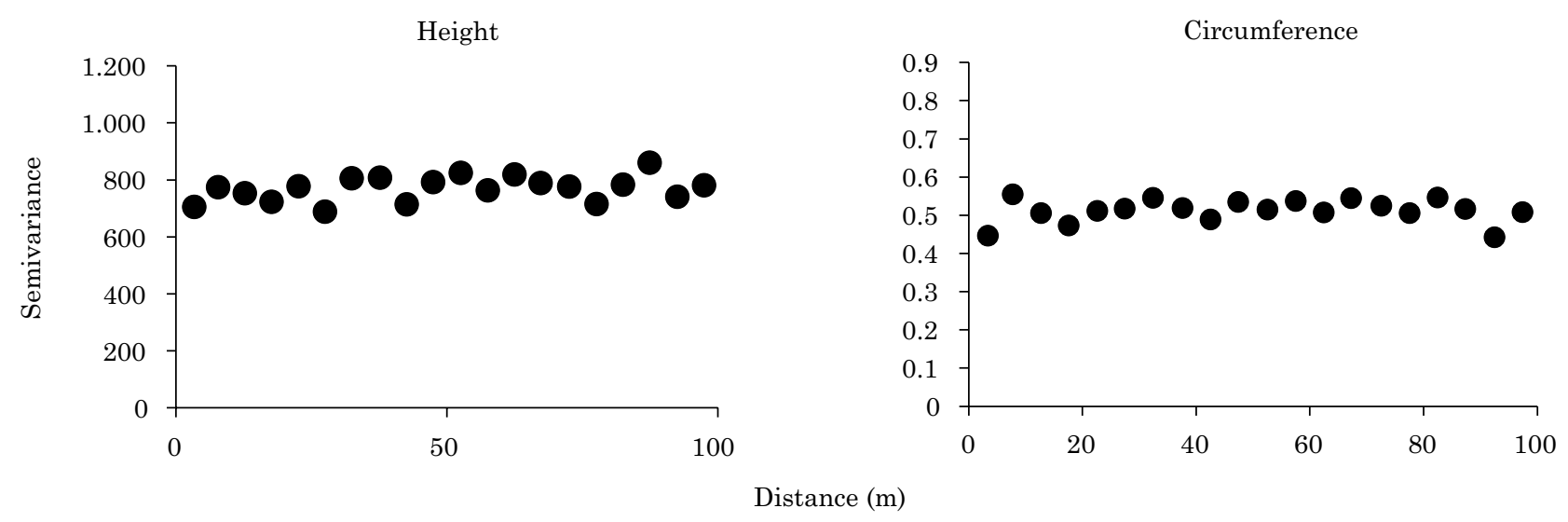

Figure 2. Semivariogram of termite nest circumference and height evaluated in Plot 3 from Pasture 2, on the Fazenda Campana, Rio Brilhante, MS. 


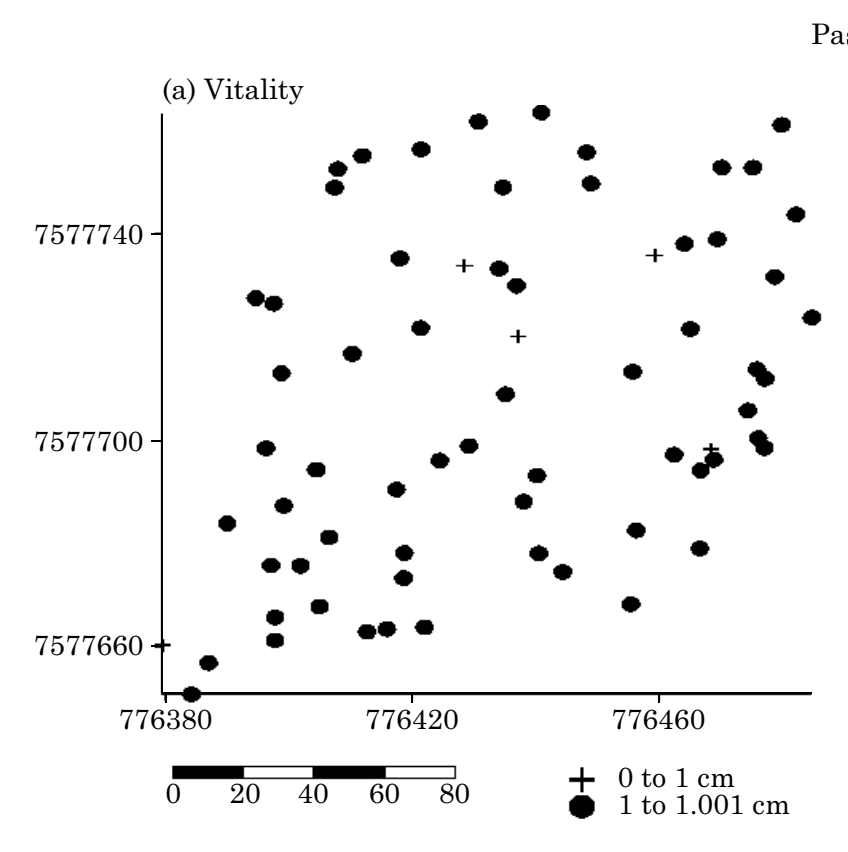

Pasture 1

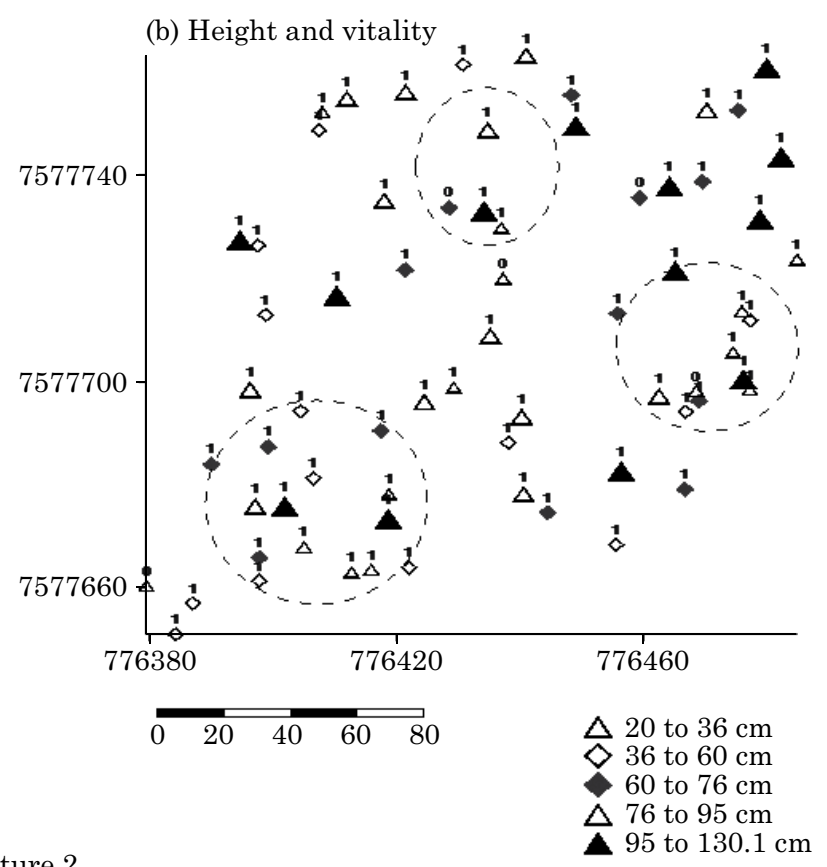

(c) Vitality
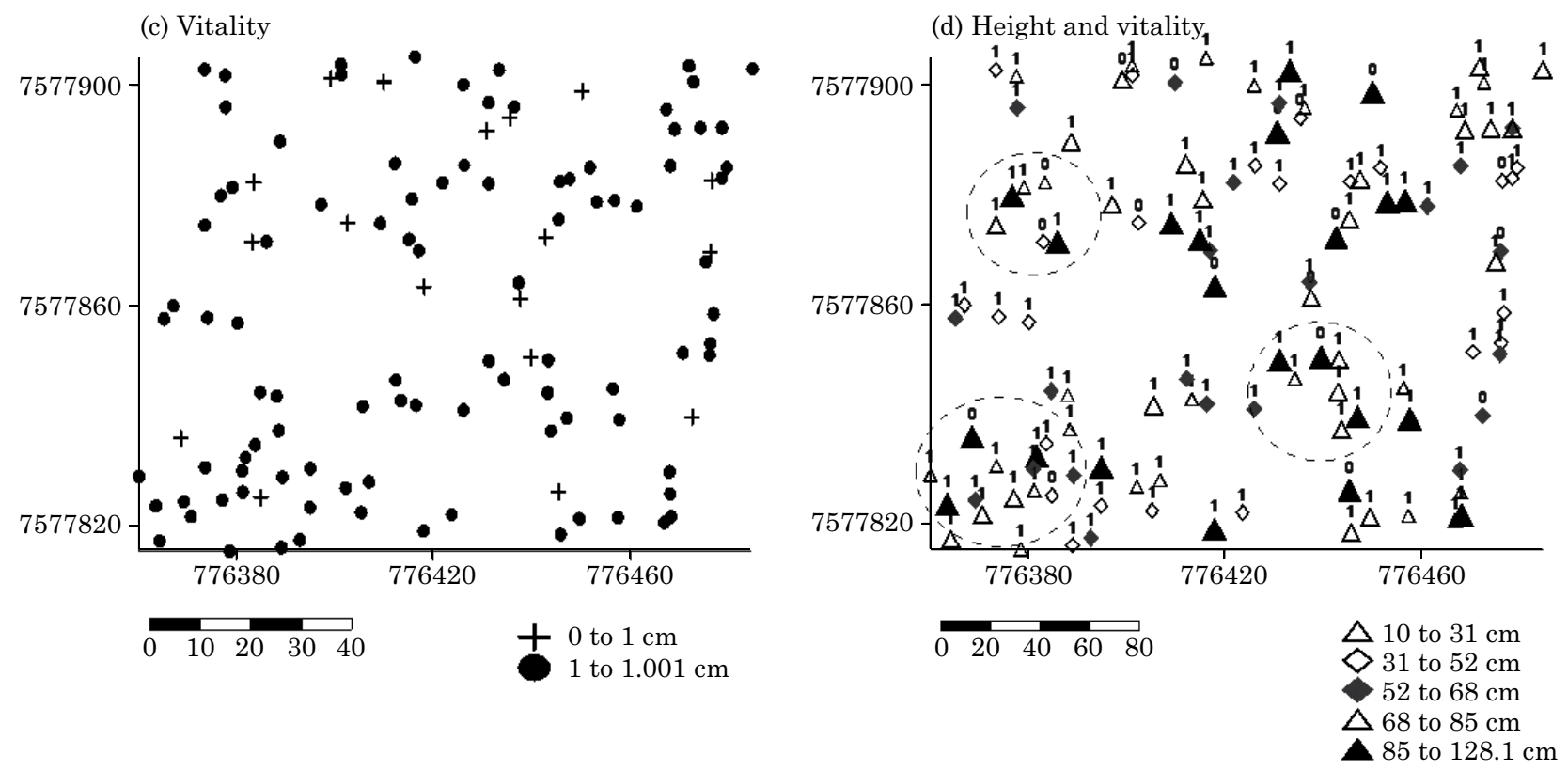

Figure 3. Spatial distribution of the vitality (a, c) and height measurements and vitality (b, d) of epigeous termite mounds in Pasture 1 and 2, respectively, on the Fazenda Campana, Rio Brilhante, MS. (+ = abandoned mounds without termite activity; $\bullet=$ active mounds). The circles in the graph explain the random distribution of mounds.

The occurrence of a single termite species (C. cumulans) likely results from the absence of old epigeous mounds, which are commonly cohabited by more than one termite species. Based on the pattern of mounds produced by C. cumulans, records on recent termite activity, mound integrity and the low mound height, the mounds analyzed were assumed to be new. Cornitermes cumulans is the most common termite species found in South-Central Brazil (Cancello, 1989). In addition, Valério et al. (2006) reported that Cornitermes is the predominant species, occupying $94 \%$ of the mounds recorded in a pasture area covered with different species of forage grass.

Our findings on the occupation of pasture areas by termite mounds are similar to those reported in previous studies conducted in the Cerrado 
(Czepak et al., 2003; Cunha and Morais, 2010). These authors found a prevalence of $C$. cumulans mounds, ranging from 0.59 to $0.65 \mathrm{~m}$ in height, and, as in this study, concluded that the mounds do not significantly compromise the area of useful pasture. The higher occurrence of mounds with low mound height and circumference in Pasture 2 (Figure 4c,d) explains the high coefficient of variation detected. Fadini et al. (2002) reported that termite mounds frequently reach a height of $1.5 \mathrm{~m}$ in pasture areas. However, Cunha (2011) found that epigeous C. cumulans mounds are on average $0.42 \mathrm{~m}$ high, which was is in line with our study. The positive correlation between circumference and height is related to mound development, and increases with colony size. Therefore, considering the shape of $C$. cumulans mounds, higher mounds have a

Pasture 1

(a) Height

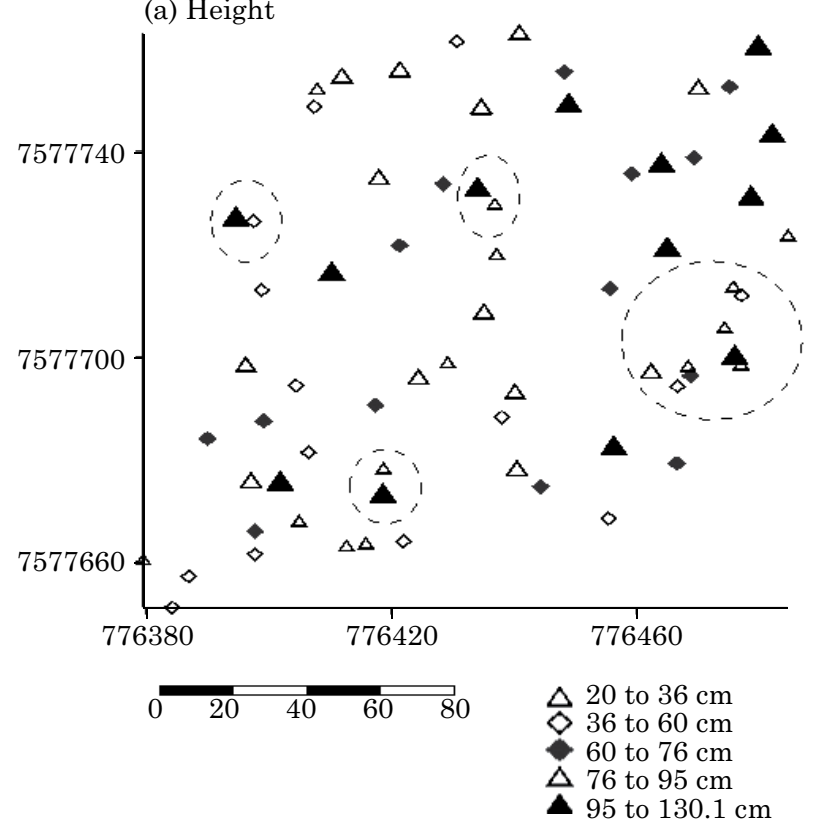

(b) Circumference

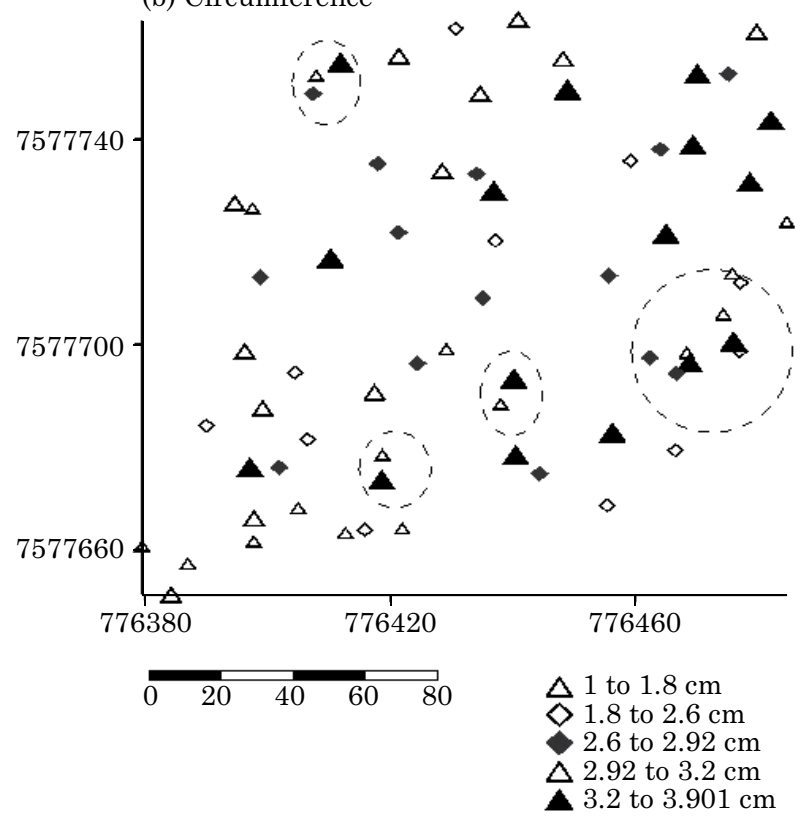

(c) Height

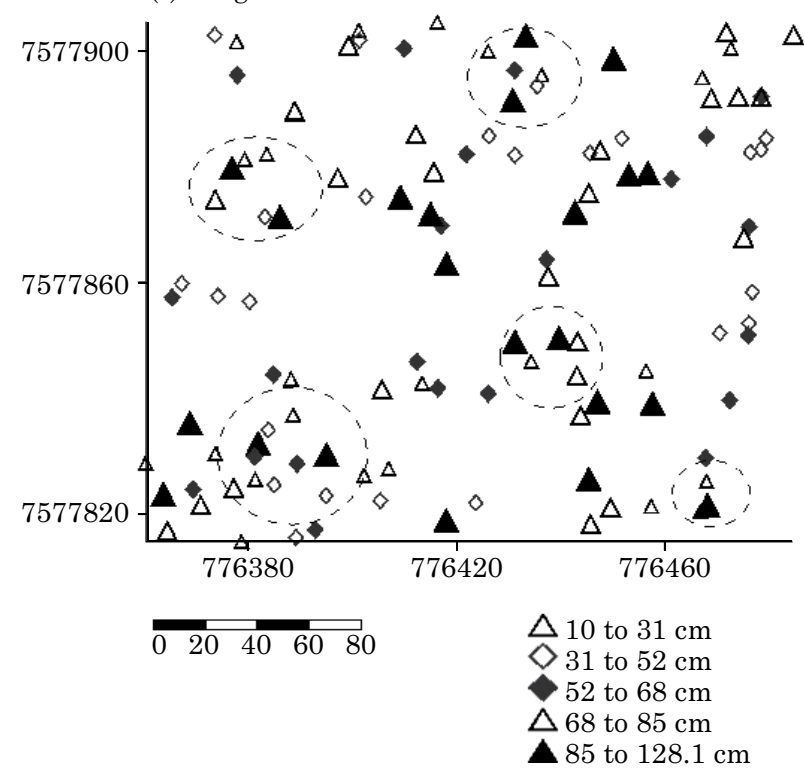

(d) Circumference

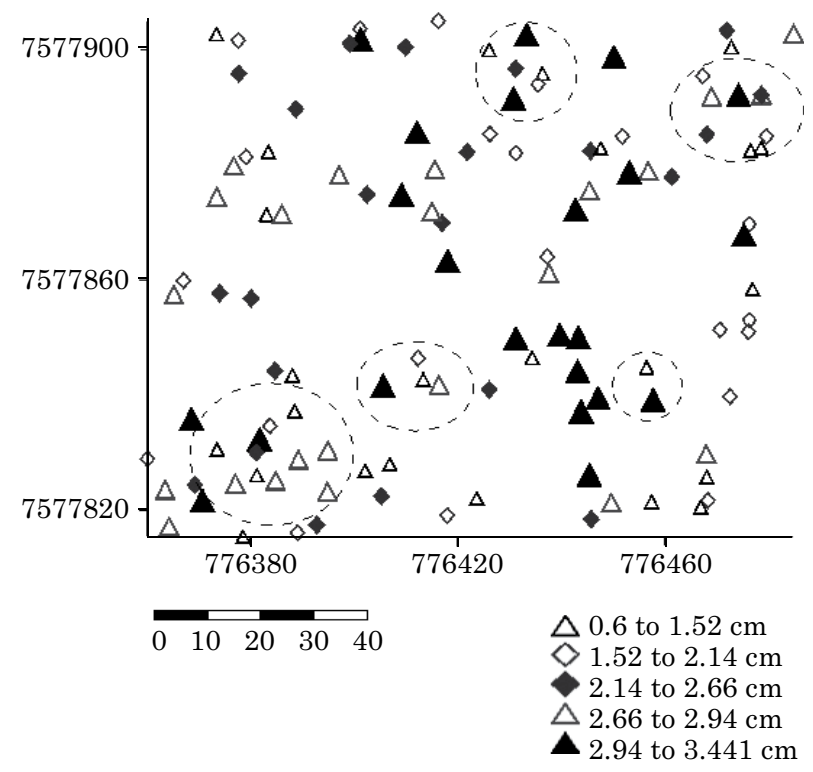

Figure 4. Spatial distribution of height $(a, c)$ and circumference $(b, d)$ measurements of epigeous termite mounds in Pasture 1 and 2, respectively, on the Fazenda Campana, Rio Brilhante, MS. The circles in the graph explain the random distribution of mounds. 
greater circumference. In older mounds, where the upper portion deteriorates due to rainfall, height commonly decreases in relation to circumference.

The results of spatial distribution agree with Grohmann et al. (2010) and Korb and Linsenmair (2001). These authors analyzed mound distribution patterns as a function of size and vitality, and although they used other methods and studied other species than in the present study, they also observed no spatial dependence of mound distribution in most plots. Crist (1998) also applied geostatistical techniques to study termites, but focused on individuals attracted by bait rather than epigeous mounds. As in the present study, the author also reported random distribution in termite mounds.

The random behavior detected in the semivariograms can be inferred in figures $3 a$ to $4 \mathrm{~b}$, where the symbols on the graphs indicate mounds of closest proximity and differences in height and circumference. These symbols show high $\gamma_{(h)}$ values at short distances. In addition, the spatial distribution of both height and circumference at these points is similar, which is expected, given the high correlation between these properties. Small mounds are usually new constructions that grow near old, large mounds. In certain cases, they can also be ramifications of a larger mound, that is, a polycalic mound.

Other studies investigated the spatial distribution of epigeous Cornitermes spp mounds in Brazil using different procedures. According to Cunha (2011), random distribution of mounds can be explained by the absence of intraspecific competition. Using a distance index, Bruschini (2006) found that low mound density (65) and absence of intraspecific competition and food resources affected the spatial distribution of mounds. Comparing these studies, Cunha (2011) took all mounds in the plots into consideration, whereas Bruschini (2006) analyzed only the inhabited.

According to Bruschini (2006), the area size may affect mound distribution and should therefore be considered in comparative results. Cunha (2011), and Korb and Linsenmair (2001) hypothesized that intraspecific competition can explain the spatial distribution of termite mounds. In addition, according to these authors, colony growth and competition for food seems to change random distribution to a more regular pattern. Moreover, Jiménez et al. (2006) reported that unequal distribution of resources can determine the spatial distribution of soil organisms, which can alternate between high and low density in a same area.

Lima et al. (2011) recorded high productivity and consequent homogeneity of food distribution for termites in both pasture areas studied. Owing to these characteristics, the hypothesis of intraspecific competition cannot explain the random spatial distribution of termite mounds. It is important to underscore that mound distribution may be directly related to flight distance and climatic conditions at flight time, most likely affecting the location of new colonies formed by breeding pairs. Since the flight distance cannot be accurately evaluated, randomness is an acceptable pattern of termite mound distribution.

The high proportion of active mounds indicates the potential for an increase in the number of mounds in the area. Oliveira et al. (2011) found higher mound occurrence (408 mounds ha-1) on the Central Cerrado Plateau. Confirming findings of Lima et al. (2011), the pasture areas studied were considered homogeneous, productive and undegraded, when assessing indicators of pasture degradation (soil fertility and microbial biomass, light fraction of organic matter, litter and existing regrowth) in the areas of this study, differing from many pastures areas in Brazil that are densely occupied by epigeous termite mounds. Ecological studies on the spatial distribution pattern and other termite mound parameters, such as vitality, are important in explaining the higher or lower formation intensity of epigeous mounds in pasture areas. Further studies should investigate this issue, testing different conditions of pasture productivity and ages.

\section{CONCLUSIONS}

In the pasture areas, the number of mounds without epigeous termite activity was much lower than that of active or inhabited mounds.

The spatial distribution of mounds was epigeous, confirming reports in the literature and suggesting the use of geostatistics as important tool for ecological studies.

The random distribution of the mounds indicates that more research is needed to explain the dynamics of termites in the soil and their relationship with biotic and abiotic factors.

\section{ACKNOWLEDGEMENTS}

The authors acknowledge the Coordination for the Improvement of Higher Level Personnel (Capes) for for a scholarship to the first author; the Brazilian Agricultural Research Corporation (Embrapa), Rio de Janeiro Research Assistance Foundation (FAPERJ) and the National Council for Scientific and Technological Development $(\mathrm{CNPq})$ for financial support; and they are indebted to Arthur Coelho Barbosa for granting access to the study area and for logistic support. 


\section{REFERENCES}

Ávila CJ, Goulart JA. Broca-cupinzeira: controle do cupim de montículo [internet]; 1995; Dourados. Dourados: Empresa Brasileira de Pesquisa Agropecuária; 1995 [accessed Mar 18 2013]. Available at: http://www.infoteca.cnptia.embrapa.br/ handle/doc/235367.

Bandeira AG, Martius C. Isoptera. In: Fonseca CRV, Magalhães C, Rafael JA, Franklin E, editores. A fauna de artrópodes da Reserva Florestal Ducke. Manaus: Instituto Nacional de Pesquisa da Amazônia; 2009.

Bandeira AG, Vasconcellos A. Efeitos de perturbações antrópicas sobre as populações de térmitas (Isoptera) do Brejo dos Cavalos, Pernambuco. In: Porto KC, Cabral JJP, Tabareli M, organizadores. Brejos de altitude em Pernambuco e Paraíba: História Natural, Ecologia e Conservação. Brasília, DF: Ministério do Meio Ambiente/Universidade Federal de Pernambuco; 2004. p.145-51.

Bruschini MLT. Spatial distribution of mounds of Cornitermes cumulans (Isoptera: Termitidae) in a pasture in the municipality of Rio Claro (SP), Brazil. Ambiência. 2006;2:65-72.

Cancello EM. Revisão de Cornitermes Wasmann (Isoptera, Termitidae, Nasutitermitinae) [tese]. São Paulo: Universidade de São Paulo; 1989.

Cancello EM, Schlemmermeyer T. Isoptera In: Brandão CRF, Cancello EM, organizadores. Biodiversidade do Estado de São Paulo, Brasil: Síntese do conhecimento ao final do século XX. Invertebrados terrestres. São Paulo: Fundação de Apoio à Pesquisa do Estado de São Paulo; 1999. p.82-91.

Clark PJ, Evans FC. Distance to nearest neighbours as a measure of spatial relationship in populations. Ecology. 1954;35:445-53.

Constantino R. Chave ilustrada dos gêneros de cupim (Insecta: Isoptera) que ocorrem no Brasil. Papeis Avulsos Zool. 1999;40:387-448.

Constantino R. Padrões de diversidade e endemismo de térmitas no bioma Cerrado. In Cerrado: ecologia, biodiversidade e conservação. In: Scariot A, Sousa-Silva JC, Felfili JM, organizadores. Brasília, DF: Ministério do Meio Ambiente; 2005. p.320-33.

Constantino R, Schlemmermeyer T. Térmitas (Insecta: Isoptera). In: Alho CJR, editor. Fauna silvestre da região do rio Manso MT. Brasília, DF: Instituto Brasileiro do Meio Aambiente e dos Recursos Naturais Renováveis; 2000. p.129-51.

Crist TO. The spatial distribution of termites in shortgrass steppe: A geostatistical approach. Oecologia. 1998;114:410-6.

Cunha HF. Distribuição espacial de cupinzeiros epígeos de pastagem no município de Iporá-GO, Brasil. Entomo Brasilis. 2011;4:45-8.

Cunha HF, Morais PPAM. Relação espécie-área em cupinzeiros de pastagem, Goiânia-GO, Brasil. Entomo Brasilis. 2010;3:60-3.

Czepak C, Araujo EA, Fernandes PM. Ocorrência de espécies de térmitas de montículo em pastagens no Estado de Goiás. Pesq Agropec Trop. 2003;33:35-8.

Eggleton P, Bignell DE, Hauser S, Dibog L, Norgrove L, Madong B. Termite diversity across an anthropogenic disturbance gradient in the humid forest zone of West Africa. Agric Ecosyst Environ. 2002;90:189-202.
Empresa Brasileira de Pesquisa Agropecuária - Embrapa. Sistema brasileiro de classificação de solos. $2^{\text {a }}$ ed. Brasília, DF; 2006.

Fadini MAM, Moino Júnior A, Souza OFF. Ecologia e manejo de térmitas de montículo em pastagens: indicações técnicas. Belo Horizonte: Empresa de Pesquisa Agropecuária de Minas Gerais; 2002. (Boletim técnico, 66).

Florencio DF, Diehl E. Termitofauna (Insecta, Isoptera) em Remanescentes de Floresta Estacional Semidecidual em São Leopoldo, Rio Grande do Sul, Brasil. R Bras Entomol. 2006;50:505-11.

Golden Software. Surfer 7.02. Surface Mapping System. Colorado: Golden Software; 2000.

Grohmann C, Oldeland J, Stoyan D, Linsenmair KE. Multi-scale pattern analysis of a mound-building termite species. Insect Soc. 2010;57:477-86.

Holt JA, Lepage M. Termites and soil properties. In: Abe T, Higashi M, Bignell DE, editors. Termites: Evolution, sociality, symbiosis, ecology. Dordrecht: Kluwer Academic; 2000. p.389-407.

Jiménez J, Decaëns T, Rossi J. Stability of the spatio-temporal distribution and niche overlap in neotropical earthworm assemblages. Acta Oecol. 2006;30:299-311.

Korb J, Linsenmair KE. The causes of spatial patterning of mounds of a fungus-cultivating termite: Results from nearest-neighbour analysis and ecological studies. Oecologia. 2001;127:324-33.

Lee KE, Wood TG. Termites and soils. New York: Academic Press; 1971.

Lima SS, Alves BJR, Aquino AM, Mercante FM, Pinheiro ÉFM, Sant'anna SAC, Urquiaga S, Boddey, RM. Relação entre a presença de cupinzeiros e a degradação de pastagens. Pesq Agropec. Bras. 2011;46:1699-706.

Lima-Ribeiro MS, Pinto MP, Costa SS, Nabout JC, Rangel TFLVB, Melo TL, Moura IO. Associação de Constrictotermes cyphergaster Silvestri (Isoptera: Termitidae) com Espécies Arbóreas do Cerrado Brasileiro. Neotrop Entomol. 2006;35:49-55.

Martius C. Structure and mound architecture in Nasutitermes populations of white-water floodplain forests in Amazonia, and a field key to the mounds of species from Ilha de Marchantaria (Isoptera: Termitidae: Nasutitermitinae). Andrias. 2001;15:163-71.

MartiuS, C. Non-linear relationships with termite swarming in Amazonia. Amazoniana. 2003;17:387-97.

Medeiros L, Bandeira A, Martius C. Termite swarming in the Northeastern Atlantic Rain Forest of Brazil. Stud Neotrop Fauna Environ. 1999;34:76-87.

Oliveira MIL, Brunet D, Mitja D, Cardoso WS, Benito NP, Guimarães MF, Brossard M. Incidence of epigeal nest-building termites in Brachiaria pastures in the Cerrado. Acta Sci Agron. 2011;33:181-5.

Rebello AMC, Martius C. Dispersal flights of termites in Amazonian forests (Isoptera). Sociobiology. 1994;24:127-46.

Valério JR. Ocorrência, danos e controle de cupins de montículo em pastagens. In: Ata e resumos da $5^{\text {a }}$. Reunião Sul-Brasileira de Insetos de Solo; 1995; Dourados. Dourados: Empresa Brasileira de Pesquisa Agropecuária; 1995. p.33-6. 
Valério JR, Barbosa LR, Pereira AA, Oliveira MCM. Percentual de cupinzeiros abandonados em pastagens de Brachiaria decumbens altamente infestadas por Cornitermes cumulans

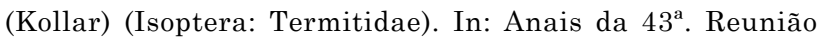
Anual da Sociedade Brasileira de Zootecnia [CD-ROM]; 24-27 jul 2006; João Pessoa. João Pessoa: Sociedade Brasileira de Zootecnia; 2006.
Vieira SR. Geoestatística em estudos de variabilidade espacial do solo. In: Novais RF, Alvarez V VH, Schaefer CEGR, editores. Tópicos em ciência do solo. Viçosa, MG: Sociedade Brasileira de Ciência do Solo; 2000. v.1, p.1-54.

Vieira SR, Hatfield JL, Nielsen DR, Biggar JW. Geoestatiscal theory and application to variability of some agronomical properties. Hilgardia. 1983;51:1-75. 